\title{
On-Site Manufacture of Large Cement Structures
}

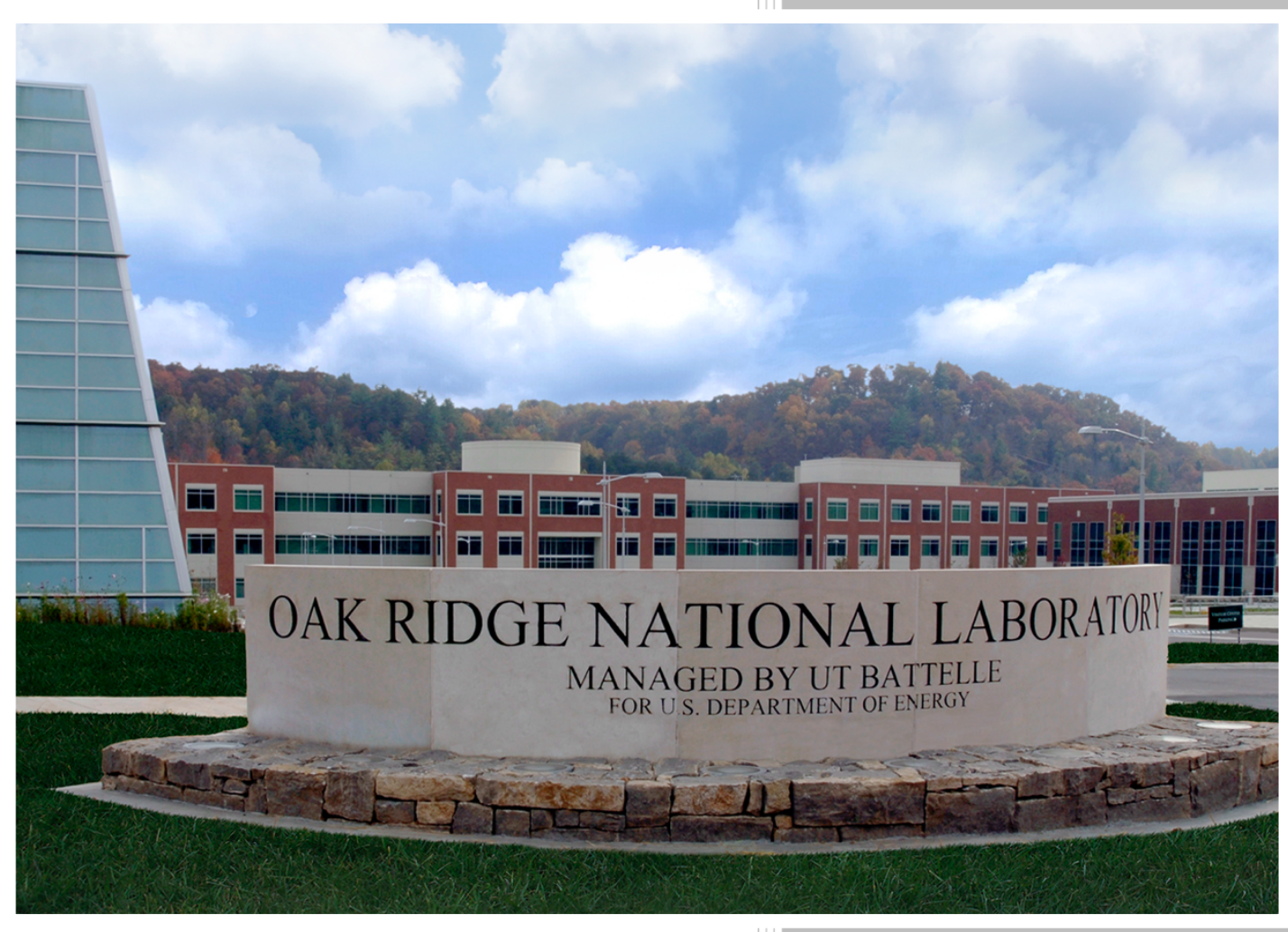

CRADA FINAL REPORT

NFE-18-07309
Brian Post

Phillip Chesser

Alex Roschli

Alex Boulger Jesse Heineman Celeste Atkins

Peter Lloyd

Randall Lind

September 2019 


\section{DOCUMENT AVAILABILITY}

Reports produced after January 1, 1996, are generally available free via US Department of Energy (DOE) SciTech Connect.

Website http://www.osti.gov/scitech/

Reports produced before January 1, 1996, may be purchased by members of the public from the following source:

National Technical Information Service

5285 Port Royal Road

Springfield, VA 22161

Telephone 703-605-6000 (1-800-553-6847)

TDD 703-487-4639

Fax 703-605-6900

E-mail info@ntis.gov

Website http://www.ntis.gov/help/ordermethods.aspx

Reports are available to DOE employees, DOE contractors, Energy Technology Data Exchange representatives, and International Nuclear Information System representatives from the following source:

Office of Scientific and Technical Information

PO Box 62

Oak Ridge, TN 37831

Telephone 865-576-8401

Fax 865-576-5728

E-mail reports@osti.gov

Website http://www.osti.gov/contact.html

This report was prepared as an account of work sponsored by an agency of the United States Government. Neither the United States Government nor any agency thereof, nor any of their employees, makes any warranty, express or implied, or assumes any legal liability or responsibility for the accuracy, completeness, or usefulness of any information, apparatus, product, or process disclosed, or represents that its use would not infringe privately owned rights. Reference herein to any specific commercial product, process, or service by trade name, trademark, manufacturer, or otherwise, does not necessarily constitute or imply its endorsement, recommendation, or favoring by the United States Government or any agency thereof. The views and opinions of authors expressed herein do not necessarily state or reflect those of the United States Government or any agency thereof. 
ORNL/TM-2019/1334

CRADA/NFE-18-07309

\title{
Energy and Transportation Sciences Division \\ Advanced Manufacturing Office
}

\section{On-Site Manufacture of Large Cement Structures}

\author{
Authors \\ Brian Post \\ Phillip Chesser \\ Randall Lind \\ Alex Roschli \\ Alex Boulger \\ Jesse Heineman \\ Celeste Atkins \\ Peter Lloyd \\ Randall Lind
}

Date Published:

September 2019

\author{
Prepared by \\ OAK RIDGE NATIONAL LABORATORY \\ Oak Ridge, Tennessee 37831-6283 \\ managed by \\ UT-BATTELLE, LLC \\ for the \\ US DEPARTMENT OF ENERGY \\ under contract DE-AC05-00OR22725
}

Approved For Public Release 



\section{CONTENTS}

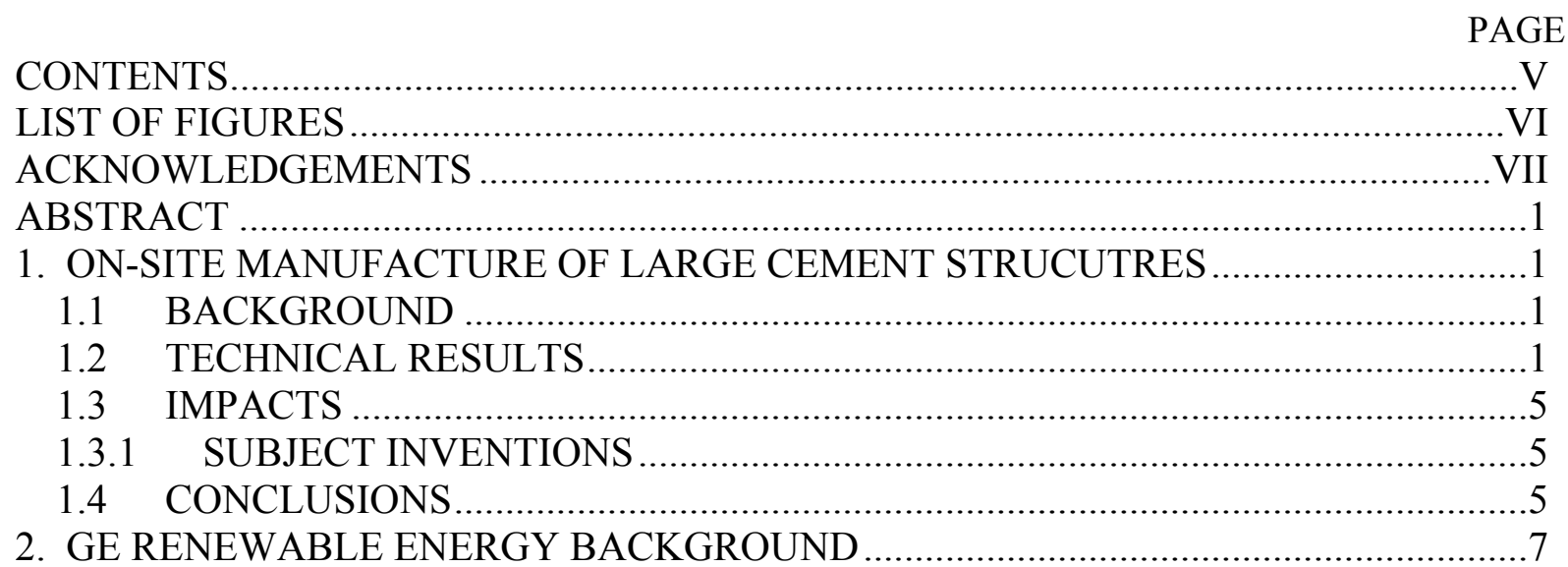




\section{LIST OF FIGURES}

Figure 1. Concrete with fiber reinforcement, tested for strength .2

Table 1. Composition of the concrete material used to print test articles..............................2

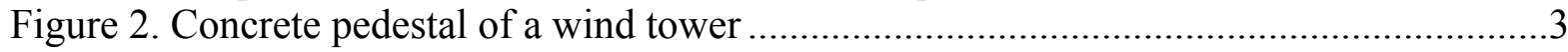

Figure 3. Test article with geometry similar to wind turbine pedestal ................................... 3

Figure 4. Maximum bond strength after various curing times. ...........................................4

Figure 5. Maximum load after various curing times. ................................................. 


\section{ACKNOWLEDGEMENTS}

This CRADA NFE-18-07309 was conducted as a Technical Collaboration project within the Oak Ridge National Laboratory (ORNL) Manufacturing Demonstration Facility (MDF) sponsored by the US Department of Energy Advanced Manufacturing Office (CPS Agreement Number 24761).

Opportunities for MDF technical collaborations are listed in the announcement "Manufacturing Demonstration Facility Technology Collaborations for US Manufacturers in Advanced Manufacturing and Materials Technologies" posted at http:/web.ornl.gov/sci/manufacturing/docs/FBO-ORNL-MDF-2013-2.pdf. The goal of technical collaborations is to engage industry partners to participate in short-term, collaborative projects within the Manufacturing Demonstration Facility (MDF) to assess applicability and of new energy efficient manufacturing technologies. Research sponsored by the U.S. Department of Energy, Office of Energy Efficiency and Renewable Energy, Advanced Manufacturing Office, under contract DE-AC0500OR22725 with UT-Battelle, LLC.

The ORNL MDF would like to acknowledge Katherine Gaul for her contribution to the preparation of this technical report. 


\begin{abstract}
Oak Ridge National Laboratory (ORNL) worked with GE Renewable Energy to develop additive manufacturing capabilities that enable the manufacture of large cement structures on-site. This project resulted in the testing and definition of the materials and deposition functions necessary for an on-site additive manufacturing system. Test articles were manufactured using a medium-scale prototype system, and mechanical testing of the samples was performed.
\end{abstract}

\title{
1. ON-SITE MANUFACTURE OF LARGE CEMENT STRUCUTRES
}

This Phase 1 technical collaboration project (MDF-TC-2018-150) began on October 30 ${ }^{\text {th }}, 2018$ and ended September $16^{\text {th }}, 2019$. The collaboration partner, GE Renewable Energy, is a large business. This project resulted in concrete components fabricated using a new additive manufacturing system and a path forward for further development.

\subsection{BACKGROUND}

Wind turbines are growing larger and larger to service greater power demands. As the wind turbines grow larger, it becomes more difficult to transport their large components. Currently, tower sections that exceed 4.3 meters cannot be feasibly transported from the factory to the field, so conventional wind turbine towers are less than 134 meters in height and 4.3 meters in diameter. However, the need to manufacture larger wind turbines continues to grow. The objective of this project was to explore the direct manufacture of wind turbine towers in the field. There are two fundamental issues that block the development of this technology. The first is the deposition of a tower material at a rate that is sufficient for economic viability. To address this issue, a material must meet be:

1) strong enough to accommodate high loads

2) available worldwide

3) suitable for high deposition rates (exceeding $0.7 \mathrm{~m} / \mathrm{hr}$ enabling a $165 \mathrm{~m}$ tower to be manufactured in under 10 days).

The second issue is the need to accurately position the deposition head and control its position and velocity over a very large area (6-meter diameter cylinder $165 \mathrm{~m}$ tall).

The first phase of this project aimed to lay the groundwork for addressing both of these issues.

\subsection{TECHNICAL RESULTS}

The project began with GE providing material specifications, such as environmental conditions and mechanical properties, for the tower's construction. They are as follows:

1. Wall thickness (bead width) is between $64 \mathrm{~mm}\left(2.5\right.$ ") and $120 \mathrm{~mm}\left(4.8^{\prime \prime}\right)$

2. The finished wall thickness (Inner wall + Poured + outer wall) between $600 \mathrm{~mm}$ and $1000 \mathrm{~mm}$

3. The desired print envelope is $5.75 \mathrm{~m}$ in diameter and $10 \mathrm{~m}$ in height at full scale

4. The overhang target is $1.0-2.0 \mathrm{deg}$

5. Print rate of $\sim 2.5 \mathrm{~m}^{3} / \mathrm{hr}$ which would allow a $10 \mathrm{~m}$ pedestal structure in a single day

6. Material Properties:

a. Youngs Modulus: $>49.5 \mathrm{GPa}$

b. Poisson: 0.2 
c. Compressive strength: $>36 \mathrm{Mpa}$

d. Tensile strength: $>3 \mathrm{Mpa}$

7. Environmental Factors:

a. Temperature for field installation: $2-30^{\circ} \mathrm{C}$

b. Wind speed: $<9 \mathrm{~m} / \mathrm{s}$

After GE provided the material specifications, ORNL began to identify and evaluate cement-based materials that would be suitable for 3D printing. ORNL concrete researchers explored many mixes and performed slump tests on various specimens to determine the best mixture for this application. Research included adding a variety of materials to the concrete mixture, such as Poraver recycled glass aggregate and metal reinforcement fibers, as seen in Figure 1.

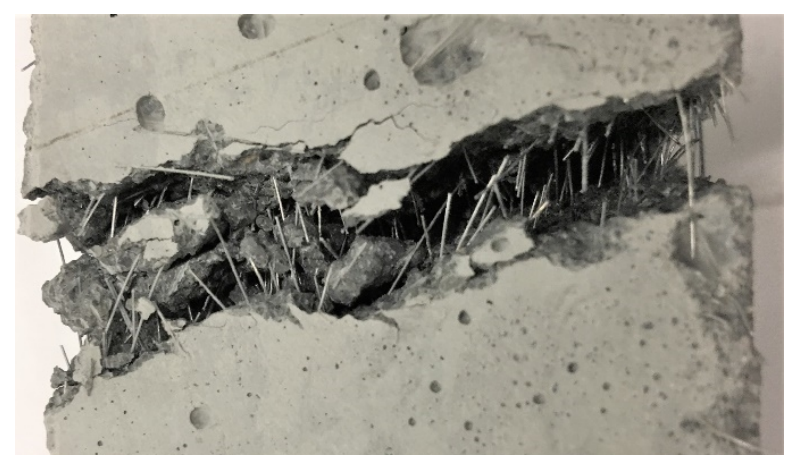

Figure 1. Concrete with fiber reinforcement, tested for strength

Because of extruder capability limitations, it was ultimately decided that a fiber-reinforced concrete mixture was not feasible at this time. Therefore, ORNL settled on the following mix to use for the fabrication of a large test article:

Table 1. Composition of the concrete material used to print test articles.

\begin{tabular}{|c|}
\hline Material \\
\hline Sand Mixture \\
\hline Type III Cement \\
\hline Blast Furnace Slag \\
\hline Silica Fume \\
\hline Water \\
\hline Glenium 7920 \\
\hline
\end{tabular}

GE provided the desired geometry for the test article. The part that was chosen was a cylinder 3 meters in diameter that was printed as tall as possible. Since the ultimate goal of this collaboration is to enable large wind turbine parts to be manufactured on-site, it made sense to test a part that was similar to the pedestal of a wind turbine. Figure 2 shows an example of a concrete pedestal for a wind turbine tower. 


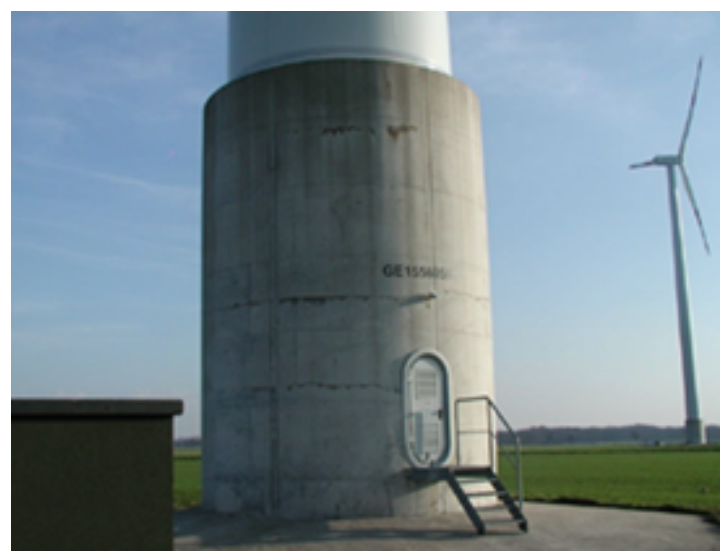

Figure 2. Concrete pedestal of a wind tower

The test article printed is the largest concrete structure printed to-date on the SkyBAAM system. The structure consists of a two-bead base that was filled with solid concrete to provide a stable foundation capable of supporting the weight of the printed structure. Then, the remaining structure was printed on top of the base, also with two beads: One outer bead and one inner bead that created the geometry shown in Figure 3. The part was printed at a speed of $1 \mathrm{in} / \mathrm{s}$ with a bead geometry of 2 x $1.5 \mathrm{in}$. The final part was $4 \mathrm{ft}$ tall with a diameter of $8 \mathrm{ft} 6 \mathrm{in}$. The weight of the final part was approximately 7,000 lbs.

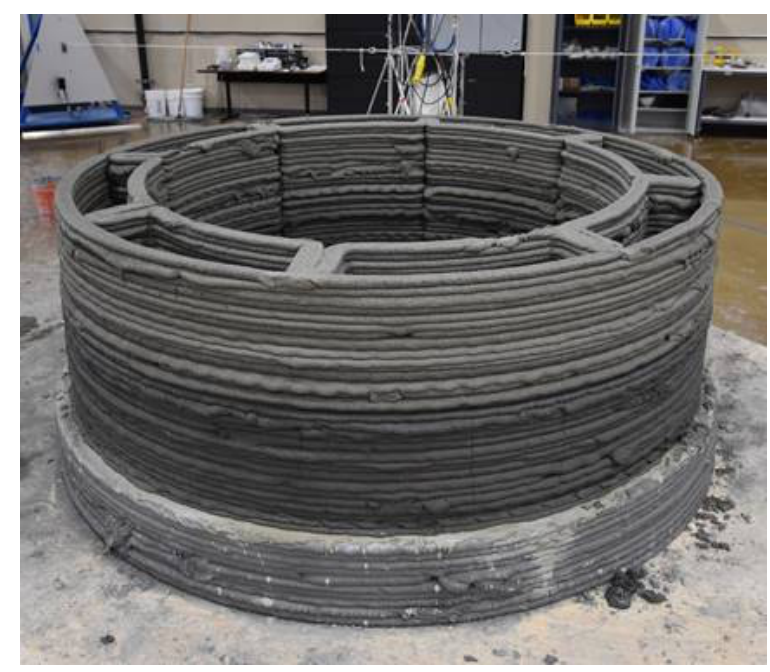

Figure 3. Test article with geometry similar to wind turbine pedestal

GE performed layer to layer mechanical testing of smaller cylindrical test articles that were 3" in diameter x 6" long, with the material composition outlined in Table 1. These samples were prepared by pouring $1 / 2$ of the concrete mixture into the mold, waiting 3 minutes, and then adding the rest of the mixture. Maximum load and bond stress tests were performed after 4, 7, 11 and 28 days of curing. The results of these mechanical tests are presented in Figures 4 and 5. 


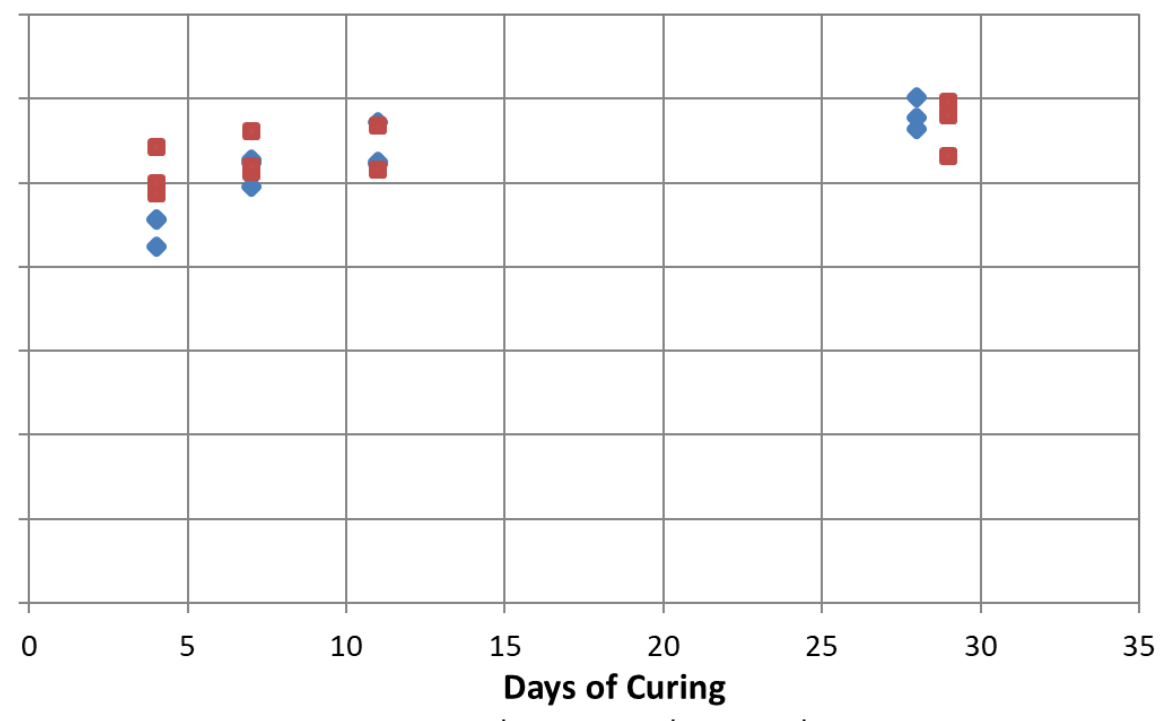

- Test Samples Baseline Samples

Figure 4. Maximum bond strength after various curing times.

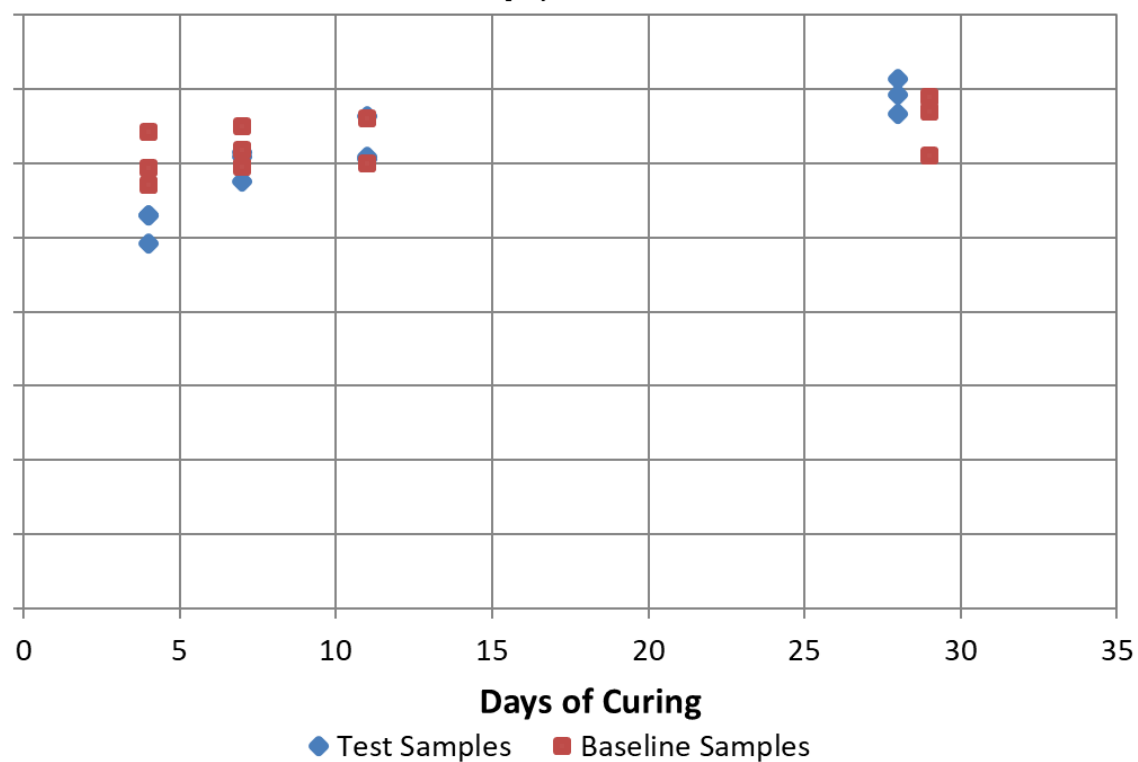

Figure 5. Maximum load after various curing times.

Mechanical tests revealed that the concrete material met all material requirements except for tensile strength. Steel fiber or rebar reinforcement will be necessary to meet that objective.

As a result of this Phase 1 project, we have proposed the following specifications for a prototype system:

- Deposition rate of $2.5 \mathrm{~m}^{3} / \mathrm{hr}$

- Print speed of $5.3 \mathrm{in} / \mathrm{s}$

- Accuracy of $+/-0.25$ in.

- Pump mechanism consisting of a concrete pump with an on-demand delivery system to a metering pump on the end effector of the manipulation system 
- Fiber (steel, glass or polymer) reinforcements added to the material mix

- Rebar and other reinforcements will be emplaced after the printed forms are complete.

\subsection{IMPACTS}

With the development of the printed wind turbine tower, large-scale additive manufacturing technology will expand from prototyping and tooling to the manufacture of structural elements. Specific technologies that were explored and demonstrated in this project include printed concrete structures and large-scale site manufacturing. If these technologies can be commercialized, especially together, this could revolutionize the U.S. wind industry.

\subsubsection{SUBJECT INVENTIONS}

There were no subject inventions as a result of this project.

\subsection{CONCLUSIONS}

ORNL was able to print a large test article that was a little under half of the size required by GE for their wind turbine application $(2.6 \mathrm{~m}(8.5 \mathrm{ft})$ in diameter vs required $5.75 \mathrm{~m}, 1.2 \mathrm{~m}(4 \mathrm{ft})$ tall vs. required $10 \mathrm{~m}(32.8 \mathrm{ft}))$. ORNL and GE have worked together to identify a basic concrete mix that meets most of the material requirements but will need fiber reinforcement to meet the tensile strength specification.

Additionally, the specifications for a prototype system have been identified.

Based on the success of this Phase 1 project, ORNL and GE aim to continue their collaboration in the form of a Phase 2 technical collaboration to advance the development of this technology. The next step is to create the prototype system and demonstrate its feasibility at the ORNL facility. This will involve successfully printing a test article with a fiber-reinforced material using a system that meets the specifications identified in this Phase 1 report. 


\section{GE RENEWABLE ENERGY BACKGROUND}

GE Renewable Energy is a division of General Electric that focuses on producing energy using renewable resources such as wind, water, and solar. GE Renewable Energy is headquartered in Paris, France and was created in 2015. GE Renewable Energy has 35,000 wind turbines installed globally, 25\% of global hydropower installations, the largest clean energy footprint of 400GW, 22,000 employees, and a presence in more than 80 countries. 